\title{
Implementasi Kedaulatan Permanen atas Sumber Daya Alam Dalam Aturan Investasi Asing di Aljazair dan Indonesia
}

\author{
Saru Arifin \\ Fakultas Hukum Universitas Negeri Semarang \\ Jln. Sekaran Gedung K, Gunungpati Semarang 50229 \\ saruarifin@mail.unnes.ac.id
}

Received: 24 Juli 2018; Accepted: 30 Oktober 2018; Published: 17 Januari 2019

DOI: 10.20885 /iustum.vol25.iss3.art3

\begin{abstract}
Since first coined by the United Nations at the end of 1950's, the doctrine of permanent sovereignty over natural resources has experienced rapid dynamics of development - from those originally traditionally practiced to the national interests of a country - then developed and intersected various global issues, such as economy, environment, human rights, and climate change. Such doctrine only confirms to the countries of the world about the importance of permanent sovereignty for each country over its natural resources. However, the management needs to pay attention to various important aspects that intersect with human interests universally and inclusively. This study uses a normative legal method to discuss the implementation of the 1950 state sovereignty doctrine over natural resources in the investment legal system of developing countries such as Africa and also Indonesia, which is actively opening up to local and international investors to improve the national economy for social welfare. The results show that the implementation of UN Resolution on permanent sovereignty of natural resources in the practice of foreign investment in Algeria is limitative, particularly towards strategic natural resources. In contrast, the practice of foreign investment in Indonesia is liberal in nature, and even its share ownership can reach one hundred percent.
\end{abstract}

Keywords: Foreign investment; permanent sovereignty; natural resources

\section{Abstrak}

Doktrin kedaulatan permanen atas sumber daya alam sejak pertama kali dicetuskan oleh PBB pada akhir dekade tahun 1950, telah mengalami dinamika perkembangan yang sangat pesat-dari yang awalnya dipraktekkan secara tradisional untuk kepentingan nasional suatu negara-kemudian berkembang dan bersinggungan dengan berbagai isu ekonomi global, lingkungan, HAM dan perubahan iklim. Doktrin ini pada prinsipnya hanya memberikan penegasan kepada negara-negara di dunia akan pentingnya kedaulatan secara permanen bagi setiap negara atas sumber daya alam yang dimilikinya. Namun demikian, pengelolaannya perlu memperhatikan berbagai aspek penting yang bersinggungan dengan kepentingan umat manusia secara universal dan bersifat inklusif. Penelitian ini menggunakan metode hukum normatif yang akan membahas tentang implementasi doktrin kedaulatan negara atas sumber daya alam 1950 dalam sistem hukum investasi negara-negara berkembang seperti Afrika dan juga di Indonesia-yang saat ini sedang giat-giatnya membuka diri terhadap investor lokal maupun internasional guna meningkatkan perekonomian nasional untuk kesejahteraan masyarakat. Hasil penelitian ini menyimpulkan bahwa penerapan Resolusi PBB tentang kedaulatan permanen atas sumber daya alam dalam praktek investasi asing di Aljazair bersifat limitative, tertutama terhadap sumber daya alam strategis. Sebaliknya, dalam praktek investasi asing di Indonesia bersifat liberal bahkan kepemilikan sahamnya bisa mencapai seratus persen.

Kata-kata Kunci: Investasi asing; kedaulatan permanen, sumber daya alam 


\section{Pendahuluan}

Pada era kolonial, masyarakat pribumi hampir pasti tidak memiliki kedaulatan terhadap dirinya maupun kekayaan alam yang dimilikinya. Semua hal dikontrol oleh penjajah untuk kepentingan mereka. Gambaran ini sebagian besar terjadi di berbagai negara di kawasan Asia dan Afrika, termasuk Indonesia ${ }^{1}$. Situasi tersebut pada awal terbentuknya PBB dirasa tidak adil bagi kemanusiaan, sehingga organisasi dunia tersebut kemudian mengeluarkan resolusi yang dikenal dengan dekolonisasi yang melahirkan dua prinsip penting yang berpengaruh besar terhadap terbangunnya peradaban yang menjunjung tinggi harkat kemanusiaan bangsa-bangsa, yaitu: prinsip self determination ${ }^{2}$ dan doctrine of sovereignty ${ }^{3}$.

Prinsip pertama, memberikan ruang kebebasan bagi bangsa-bangsa terjajah untuk secara mandiri menentukan nasib mereka dalam sebuah ikatan kebangsaan dan kenegaraan. Sedangkan yang kedua, memberikan kesetaraan kedaulatan bagi setiap negara di muka hukum untuk membangun negaranya menuju kemakmuran dan kesejahteraan bangsanya. Namun demikian, hal itu masih dirasa belum memadai, karena untuk bisa membangun kesejahteraan suatu bangsa dalam setiap negara, diperlukan kapital yang besar, maka kemudian PBB mengeluarkan resolusi 1803 (XVII) pada 14 Desember 1962 yang dikenal dengan Permanent Sovereignity over Natural Resources (PSNR) ${ }^{4}$ atau Kedaualatan Permanen atas Sumber Daya Alam (KPSA).

${ }^{1}$ William M-Adam and Martin Mulligan, mengulas secara komprehensif mengenai hubungan antara dekolonisasi dengan sumberdaya alam. Mereka menjelaskan bagaimana penduduk yang dijajah "menyambut dengan sukacita" adanya resolusi dekolonisasi yang dilakukan oleh negara-negara Eropa selama berabad-abad khususnya di kawasan Afrika dan Asia Selatan-yang memberikan kedaulatan penuh terhadap sumber daya alam dan budaya secara mandiri. Lihat pembahasannya secara detail dalam William M-Adam and Martin Mulligan, 2003. Decolonizing Nature: Strategies for Conservation in a Post-colonial Era, Earthscan Publications Ltd, London, hlm. 5.

${ }^{2}$ Hak ini pada awalnya digagas oleh Presiden Woodrow Wilson pada tahun 1918. Namun tidak populer hingga akhirnya pada tahun 1945 Uni Soviet memunculkannya dalam Konferensi PBB di Sanfransisco. Ulasan secara komprehensif menegnai self determination ini bisa dibaca dalam bukunya Hurs Hannum, 2016. Authonomy, Sovereignty, and Self Determination: The Accommodation of Conflicting Rights, University of Philadelpia Press.

${ }^{3}$ Hak ini dipelopori oleh Komisi HAM Majelis Umum PBB melalui badan ECOSOC pada tahun 1954 yang diberikan tugas untuk melakukan survei mengenai KPSA dengan tujuan untuk mendapatkan informasi yang komprehensif mengenai hak-hak permanent tersebut untuk membuat rekomendasi-rekomendasi dan penguatan. Perjuangan getol dilakukan oleh 16 negara berkembang dari Amerika Latin, Afrika dan Asia untuk mengegolkan konsep KSPA tersebut. Perdebatan sengit terjadi antara kelompok-kelompok pengusung dengan negara-negara Barat yang cenderung oposan, utamanya terjadi pada salah satu sidang pada tahun 1959. Perwakilan Chile menegaskan bahwa: "Freedom and Independence counted for nothing if they had no economic basis. National sovereignty must be exercised over entire territory and wealth of a nation,...".

${ }^{4}$ Ulasan KPSA ini dapat dibaca pada bukunya Marc Bungenber dan Stephan Hobe (Eds). 2015, Permanent Sovereignity over Natural Resources, Switzerland: Springer International Publishing, hlm. 1-13. Sementara sejarah detail mengenai KPSA ini dapat dibaca pada tulisan Stephen M. Schwebel, The Story of the U.N.'s Declaration on Permanent Sovereignity over Natural Resources, American Bar Association Journal, Vol. 49, No. 5 (MAY 1963), pp. 463-469. 
Resolusi ini embrio awalnya muncul dalam perdebatan mengenai HAM di Chile pada 1952. Selanjutnya, ide tersebut bergulir pada setiap sidang-sidang PBB sebelum akhirnya pada 1962 secara sah dideklarasikan. Menariknya, 87 anggota PBB secara bulat menyetujui resolusi tersebut, hanya Perancis dan Afrika Selatan yang melakukan dissenting, dan negara-negara Komunis kecuali Kuba yang terangterangan menentang, serta Ghana dan Burma menyatakan keduanya mengambil sikap abstain 5 .

Deklarasi tersebut terinspirasi oleh munculnya deklarasi dekolonisasi ${ }^{6}$ sebelumnya yang memberikan ruang hak menentukan nasib sendiri7 bagi semua bangsa-bangsa di dunia, utamanya mereka yang berada di bawah rezim kolonial ${ }^{8}$. Pada awalnya resolusi KPSA ini berbasis pada pemahaman tradisional dalam pengelolaan sumber daya alam yang diorientasikan untuk kepentingan nasional saja. Sementara kerjasama dalam ekplorasi dan eksploitasi atas sumber daya alam tidak diberikan ketentuan sama sekali dalam resolusi tersebut. Demikian juga persoalan tentang pembangunan berkelanjutan dan lingkungan juga tidak diatur ${ }^{9}$. Oleh sebab itu, negara-negara seperti Amerika, Inggris dan Perancis sedikit keras menentang dan berkeinginan membatasi kedaulatan permanen atas sumber daya alam dan memastikan adanya ketentuan bahwa keberadaan sumber daya alam peruntukannya dalam kepentingan kerjasama ekonomi global10.

\footnotetext{
${ }^{5}$ Stephen M. Schwebel, 1963. The Story of the U.N's. Declaration on Permanent Sovereignity Over Natural Resources, dalam <https://heinonline.org/HOL/LandingPage?handle=hein.journals $/$ abaj49\&div=113\&id=\&page=>, diakse tanggal 5 Agustus 2018.

${ }^{6}$ Secara formal, deklarasi dekolonisasi itu dilakukan pada tanggal 14 Desember 1960 melalui Resolusi PBB 1514 (XV) dengan judul: the Declaration on the Granting of Independence to Colonial Countries and Peoples. Resolusi ini disetujui oleh 89 anggota dan hanya 9 yang abastain. Dan selanjutnya, resolusi ini melahirkan banyak negara baru yang memerdekan diri dari para penjajah. Lihat De Waart, P. 1977. "Permanent Sovereignty over Natural Resources as a Corner-stone for International Economic Rights and Duties". Netherlands International Law Review, 24(1-2), 304-322. doi:10.1017/S0165070X00016302. Uraian mengenai dekolonisasi bisa juga dibaca secara komprehensif dalam tulisan Strang, D. 1990. "From Dependency to Sovereignty: An Event History Analysis of Decolonization 1870-1987”. American Sociological Review, 55(6), pp. 846-860. Retrieved from http://www.jstor.org/stable/2095750.

${ }^{7}$ Menurut Larence Astegbua, didalam hak menentukan nasib sendiri (self determination) juga terkandung kedaulatan permanen atas sumber daya alam. Lihat Atsegbua, L. 1993. "Principle Of Permanent Sovereignty Over Natural Resources and Its Contribution to Modern Petroleum Development Agreements". Journal of the Indian Law Institute, 35(1/2), 115-126. Retrieved from http://www.jstor.org/stable/43952327.

8 Pada awalnya, KPSA ini bernilai soft law, lalu pada tahun 2005 ICJ secara resmi mengakuinya sebagai prinsip hukum kebiasaan internasional yang penting. Lihat Andre Thomashausen, 2015. (Forein) Investment Strategies inAfrica dalam Marc Bungenber dan Stephan Hobe (Eds). Permanent Sovereignity over Natural Resources, Springer, hlm. 156.

9 Pasal 1 UNGA 1962.

${ }^{10}$ Chris Amstrong, 2014. Melawan Kedaulatan Permanen atas Sumber Daya, University of Southampton, Politics, Philosophy and Economics, hlm. 2.
} 
Tujuan utama dari Deklarasi KPSA ini adalah untuk memberikan kedaulatan bagi negara-negara berkembang yang baru merdeka terhadap sumber daya alam yang mereka miliki untuk kepentingan pembangunan negara mereka. Namun, seiring dengan munculnya rezim hak asasi manusia dan perlindungan lingkungan, saat ini konsep KPSA tidak lagi berfokus pada kepentingan nasionalnya saja, melainkan perlu adanya hubungan timbal balik antara negara-negara maju dan berkembang dalam pengelolaan sumber daya alam dalam konsep pembangunan berkelanjutan ${ }^{11}$. Hal ini kemudian melahirkan perkembangan konsep tentang The New International Economic Order pada 1974. ${ }^{12}$

Dalam perkembangannya, Resolusi PBB yakni Permanent Sovereignty over Natural Resources (1964) diperkuat lagi dengan Resolusi PBB lainnya tentang Charter of Economic Rights and Duties of States (1974). Kedua resolusi tersebut menjadi dasar hukum yang kuat bagi negara-negara bekas jajahan untuk melakukan penataan terhadap sumber daya alam yang ada di dalam negerinya—sebagai modal penting untuk membangun negaranya. Pada konteks ini, Resolusi 1974 memberikan tiga pilihan bagi negara-negara tersebut dalam pemanfaatan sumber daya alam yang dimilikinya, medayagunakannya secara mandiri, membuka diri atas investasi asing atau melakukan tindakan nasionalisasi SDA yang dikuasai oleh asing dan/atau mentransfer kepemilikannya kepada pribumi ${ }^{13}$.

Terkait dengan hal itu, sumber daya alam memiliki peranan yang strategis bagi kekayaan nasional suatu negara di dunia. Namun demikian, bagi negaranegara tertentu tidak selalu demikian. Misalnya, Hongkong, Jepang, Luxemberg, Singapura, Swiss dan Korea Selatan adalah contoh dari negara-negara kaya yang tidak memiliki sumber daya alam sendiri ${ }^{14}$.

\footnotetext{
${ }^{11}$ Loc. Cit.

12 Lihat Resolusi 3281 (XXIX) tentang Charter of Economic Rights and Duties of States.

13 Ibid., Pasal 2.
}

14 Thorvaldur Gylfason dan Gylfi Zoega, Natural Resources and Economic Growth: The Role of Investment, The World Economy, 2006. Blackw ell Publishing L.td. Oxford, hlm. 1091. Deskripsi mengenai perbedaan antara negara kaya dan miskin dalam kaitannya dengan sumber daya alam dapat dibaca dalam bukunya Daron Acemoglu dan James A. Robinson, 2012. Why Nations Fail: The Origin of Power, Prospherity, and Poverty. Crown Business, New York, hlm. 48 etseq. Para penulis dari kedua publikasi tersebut memberikan satu pandangan yang sama bahwa kemajuan ekonomi suatu negara tidak cukup hanya dngan mengandalkan kekayaan sumber daya alam saja, tetapi ada saling keterkaitannya antara sumber daya alam dengan level pendidikan masyarakatnya, investasi dan kebebasan sipil. Khusus pada poin ketiga ini Daron dan James menggarisbawahi bahwa sistem negara yang tertutup (sebagai lawan dari demokrasi) cenderung kemajuannya sangat lambat atau bahkan stagnan. Mereka memberi contoh bagaimana perbedaan kedua negara serumpun antara Korea Utara dan Korea Selatan dengan 
Di Indonesia, jauh sebelum Resolusi PBB tentang KPSA tersebut dideklarasikan telah menegaskan tentang kedaulatan terhadap sumber daya alam dalam UUD 1945 khususnya Pasal 33 yang pada prinsipnya menekankan bahwa bumi, air, dan kekayaan alam yang terkandung didalamnya dikuasai oleh negara dan digunakan untuk sebesar-besar kemakmuran rakyat. Ini adalah prinsip kedaulatan dan sekaligus orientasi pengelolaan sumber daya alam sebagai kapital penting dalam membangun masyarakat dan negara Indonesia. Namun, ternyata dalam perjalanan waktu, Indonesia tidak memiliki kemampuan untuk melakukan produksi secara mandiri, dikarenakan tidak adanya modal yang cukup, baik finansial maupun teknologi, sehingga untuk bisa melakukan produksi terhadap sumber daya alam yang dimilikinya, maka Indonesia sebagai pemilik SDA tersebut membuka diri bagi para investor asing untuk melakukan eksplorasi dan produksi. Pada titik inilah kemudian perdebatan "moral dan keadilan antara ekonomi, lingkungan dan masyarakat" dalam dekade terakhir sering memicu perdebatan dan pergolakan di masyarakat yang menuntut nasionalisasi perusahaanperusahaan asing. Hal ini dikarenakan faktor ketidakadilan ekonomi, terutama karena tidak adanya perbedaan perlakuan (equality treatment) antara pemodal asing dengan pemodal dalam negeri, sehingga berdampak pada terjadinya dominasi kedudukan modal asing dan mendorong minimalisasi peran negara untuk meproteksi fundamental ekonomi bangsa, termasuk proteksi terhadap pemodal dalam negeri ${ }^{15}$.

Sementara itu, di Afrika yang mayoritas negaranya bekas jajahan dari negaranegara Eropa, seperti Aljazair, menerapkan sistem investasi asing dalam pendayagunaan sumber daya alamnya melalui kebijakan investasi langsung (Foreign Direct Investment). FDI yang diterapkan di Aljazair dilakukan secara selektif untuk memproteksi sumber daya alam yang memiliki nilai ekonomi fundamental terhadap bangsanya dibatasi. ${ }^{16}$

\footnotetext{
menggunakan citra satelit di malam hari, dimana pada bagian utara (Korut) tampak banyak gelapnya, sementara dibagian selatan (Korsel) terlihat begitu terang-benderang. Hal ini menurut mereka dikarenakan perbedaan ketersediaan listrik yang mampu diusahakan negara sebagai salah satu indikator kemakmuran sangat mencolok perbedannya.

15 Dhuhita Driyah Supapti, "Dialektika Hukum Investasi Nasional”, Paper disampaikan dalam Dies Natalis Fakultas Hukum, UNNES, Semarang, 30 November 2018, hlm.12.

${ }^{16}$ Lihat dalam Aljazair Invesment Code of 1966.
} 
Berdasarkan pemaparan di atas, maka penelitian ini secara komparatif akan menganalisis penerapan Konvensi PBB tentang Kedaulatan Permanen atas Sumber Daya Alam dalam sistem hukum investasi asing yang berlaku di Indonesia dan Ajazair sebagai negara yang sama-sama bekas jajahan dari negara lain, untuk melihat perbedaan-perbedaan apa yang ada pada kedua negara ini dalam penerapan kebijakan investasi asing.

\section{Rumusan Masalah}

Berdasarkan deskripsi pada latar belakang di atas, permasalahan penelitian ini adalah bagaimana implementasi Resolusi PBB tentang Kedaulatan Permanen atas Sumber Daya Alam dalam aturan investasi langsung dari pihak asing pada sektor SDA yang strategis di Aljazair dan Indonesia?

\section{Tujuan Penelitian}

Penelitian ini memiliki tujuan untuk menganalisis penerapan Resolusi PBB tentang KPSA dalam aturan investasi langsung pihak asing pada sektor SDA yang strategis di dua negara berkembang yang memiliki latar belakang historis yang sama-sama pernah menjadi negara jajahan sebelum menjadi negara yang independen, yakni Indonesia dan Aljazair.

\section{Metode Penelitian}

Penelitian ini menggunakan metode penelitian yuridis-normatif dengan menggunakan pendekatan perundang-undangan dan pendekatan kasus ${ }^{17}$. Dalam konteks ini, peneliti melakukan penelitian terhadap sejumlah Resolusi PBB dan data sekunder yang berkaitan dengan Kedaulatan Permanen atas Sumber Daya Alam serta Resolusi lainnya yang terkait. Selain itu, penelitian dilakukan secara komparatif terhadap peraturan di dua negara bekas kolonial, yakni Aljazair dan Indonesia, mengenai implementasi Resolusi PBB tentang KPSA tersebut dalam kebijakan investasi asing di kedua negara tersebut secara komparatif-untuk menemukan titik perbedaan mendasar serta pengaruhnya terhadap dinamika pembangunan ekonomi di kedua negara tersebut. Metode analisis data dilakukan

17 Riduwan, Metode \&o Teknik. Menyusun Tesis, Penerbit Alfabet, Bandung, 2004, hlm. 42-46. Lihat juga Sugiyono, Metode Penelitian Administrasi, Penerbit Alfabet, Bandung, 2004, hlm. 65-68. 
secara deskriptif terhadap data yang telah dikumpulkan untuk menjawab pertanyaan penelitian ini.

\section{Hasil Penelitian dan Pembahahasan}

Pada bagian ini akan dideskripsikan tiga sub bahasan yang saling terkait untuk menjawab permasalahan penelitian ini. Pembahasan akan diawali dengan mendiskripsikan kerangka konseptual mengenai pengertian sumber daya alam sebagai pijakan dasar dalam memahami konteks permasalahan yang menjadi pokok penelitian ini. Selanjutnya, akan dipaparkan tentang bagaimana implementasi KPSA dalam kebijakan investasi di Aljazair dan di Indonesia secara berurutan-sebelum kemudian diakhiri dengan simpulan untuk menjawab permasalahan penelitian ini.

Dalam hukum internasional, pengertian sumber daya alam bisa ditemukan dalam Pasal 2 Konvensi PBB tentang Continental Shelf 1958 dan UNCLOS 1982 Pasal 77 yang menyebutkan bahwa:

The natural resources...consist of the mineral and other non-living resources of the seabed and subsoil together with living organism belonging to sedentary species, that is to say, organism which, at the harvestable stage, either are immobile on or are unable to move except in constant physical contact with the seabed or the soil.

Sementara itu, Konvensi Afrika 1968 tentang Konservasi Alam dan Sumber Daya Alam memberikan definisi sumber daya alam secara terbatas pada sumber daya alam terbarukan, seperti tanah, air, flora dan fauna. Adapun Konvensi Biodiversity 1992 memberikan definisi sumber daya biologi yang mencakup sumber daya genetika, organisme, populasi dan komponen biotik ekosistem lainnya yang memiliki nilai tambah bagi kemanusiaan. Pengacara dari Argentina Cano dalam laporan terhadap Food and Agricultural Organization (FAO) PBB pada 1975 memberikan pengertian tentang SDA mencakup seluruh aspek dari sumber daya alam yang bersifat fisik dan bukan buatan manusia atau sumber daya budaya ${ }^{18}$.

Selain itu, Chris Amstrong19 mendefinisikan sumber daya alam sebagai bahan baku (materi dan energi) yang tidak dibuat oleh manusia, tetapi merupakan

\footnotetext{
${ }^{18}$ Nicolaas Jan Schrijver, Sovereignty over Natural Resources: Balancing Rights and Duties in an Interdependent World s.n. University of Groningen, 1995, hlm. 14.

${ }^{19}$ Op. Cit., hlm. 5.
} 
sesuatu yang tersedia untuk mendukung aktivitas kehidupan manusia. Sementara Organisation for economi Co-operation and Development/OECD) menjelaskan bahwa sumber daya alam adalah aset alam (bahan baku) yang ada melalui proses alamiah yang dapat digunakan untuk produktifitas ekonomi atau untuk konsumsi.

Dalam sistem hukum Indonesia, definisi tentang sumber daya alam tidak secara detil didefinisikan, namun hanya disinggung dalam berbagai aturan hukum terkait. Definisi yang mulai jelas terlihat dalam Rancangan Undang-Undang tentang Pengelolaan Sumber Daya Alam yang diartikan sebagai semua benda, daya, keadaan, fungsi alam dan makhluk hidup yang merupakan hasil proses alamiah, baik hayati maupun non hayati, terbarukan maupun tidak terbarukan ${ }^{20}$. Pengertian ini memfokuskan pada sifat alamiah dari sumber daya yang ada bukan artifisial atau buatan manusia.

Perbedaan perspektif dalam mendefinisikan sumber daya alam tersebut, diakui oleh World Trade Organization (WTO), sebagai sesuatu yang jamak ditemukan khususnya dalam praktek perdagangan internasional. Oleh sebab, itu dalam kaitan ini, penulis sepakat dengan definisi WTO sendiri yang menjelaskan bahwa yang dimaksud dengan sumber daya alam adalah stok material yang tersedia di lingkungan alam, baik yang langka maupun yang bisa didayagunakan untuk ekonomi dalam kegiatan produksi maupun konsumsi. Berdasarkan definisi ini, menurut WTO, barang-barang hasil produksi pabrik seperti otomotif dan komputer tidak dikualifikasikan sebagai sumber daya alam. Secara singkat, sumber daya alam adalah semua yang eksis di dalam bumi dan tidak bersifat $\operatorname{artifisial}^{21}$.

Definisi SDA dari WTO memiliki kedekatan konsepsi dengan apa yang dimaksudkan oleh doktrin KPSA yang menekankan pada sumber daya alam yang eksis di bumi dan tidak artifisial. Oleh sebab itu, beragam regulasi baik dalam bentuk aturan regional, konstitusi maupun aturan organik dari masing-masing negara terhadap penerapan KPSA cukup beragam. Sebagian negara seperti di Afrika pada awalnya menerapkan KPSA secara terbatas untuk kepentingan

\footnotetext{
${ }^{20}$ Definisi ini diambil dari RUU Pengelolaan Sumber Daya Alam.

${ }^{21}$ WTO, "Natural Resources: Definitions, Trade Patterns and Globalization", World Trade Report, 2010, hlm.46.
} 
nasional dari negara-negara yang ada. Namun, PBB melalui berbagai organ yang dimilikinya mengeluarkan berbagai konvensi dan deklarasi yang berupaya untuk menciptakan keadilan global dalam pengelolaan sumber daya alam.

Misalnya, konsep sustainabe development atau pembangunan berkelanjutan 22 menekankan pada pemanfaatan sumber daya alam secara berkesinambungan dengan kepentingan generasi mendatang. Dengan kata lain bahwa pembangunan yang ada sekarang sebisa mungkin tidak melakukan eksploitasi terhadap SDA yang berlebihan, sehingga berdampak buruk terhadap generasi yang akan datang, terutama pada sektor-sektor non renewable resources. Negara-negara yang memiliki sumber daya alam dalam kategori tidak bisa diperbarui dianjurkan untuk tidak secara massif mengeksploitasi alam atas alasan pembangunan dan ekonomi untuk kepentingan generasi yang sekarang saja tanpa memperhatikan generasi yang akan datang.

Persoalan lain yang menjadi perhatian dunia saat ini adalah perubahan iklim dengan berbagai dampak negatif yang ditimbulkannya. Isu ini juga memiliki keterkaitan dengan isu pembangunan secara berkelanjutan. Namun, penekanan yang penting pada kedua isu tersebut adalah kearifan dalam mengatur tentang tuntutan antara konservasi dan produksi23. Konservasi menekankan pada pemeliharaan terhadap eksistensi SDA dan memperlakukannya sesuai dengan kebutuhan secara bertanggungjawab. Sementara produksi menekankan kepada kepentingan ekonomi, pembangunan, kesejahteraan dan juga kapitalisasi. Jika orientasi produksi menggunakan perspektif kapitalisme, maka sudah dapat dibayangkan bagaimana kehancuran lingkungan akan dirasakan oleh masyarakat.

\footnotetext{
${ }^{22}$ Sustainable Development Goals (SDGs) ini dicetuskan oleh PBB pada 21 Oktober 2015 yang disepkati oleh 193 negara meninggalkan program sebelumnya yaitu MDGs (Millenium Development Goals) sebagai tujuan pembangunan sampai dengan 2030. SDGs ini memiliki 17 tujuan dengan 169 target yang bersifat global. Secara filosofis pembangunan berkelanjutan bermakna saling menghormati, menghargai, inklusif, dan berlaku adil. Dalam hal ini, tujuan pembangunan tidak hanya untuk saat ini dan hanya bagi golongan tertentu tapi juga memperhatikan keberlangsungan antar generasi dan menjaga keseimbangan dengan alam dan makhluk hidup lain. Adapun keadilan berarti pencapaian pembangunan di satu sisi tidak boleh mengorbankan tujuan lainnya. Lihat dalam http://sdgsindonesia.or.id/index.php/sdgs/item/178-tujuan-pembangunan-berkelanjutan.

${ }^{23}$ Salah satu perusahaan yang telah berkomitment untuk menjaga keseimbangan tersebut contohnya adalah PT Austindo Nusantara Jaya Tbk (ANJ) sebagai induk dari kelompok perusahaan yang bergerak di bidang perkebunan dan pengolahan kelapa sawit maupun sagu, serta produksi energi terbarukan. Mereka menegaskan bahwa: "Bagi kami menjalankan bisnis yang beretika bukan sekadar slogan, namun sudah menjadi komitmen di seluruh kelompok usaha ANJ bahwa pengembangan usaha harus senantiasa seimbang dengan pelestarian lingkungan dan kemajuan masyarakat sekitar”. Lihat dalam https://anj-group.com/id/news-events-1/index/jagakeseimbangan-ekonomi-dan-lingkungan-pt-kal-bangun-kawasan-konservasi-1.
} 
Kedaulatan Permanen atas Sumber Daya Alam dalam praktek di bangsabangsa di dunia ini, pengelolaannya sangat bervariasi. Prinsip ini hanya memberikan pernyataan moral agar setiap bangsa dan negara memiliki modal kapital yang kuat dalam rangka mewujudkan kesejahteraan masyarakatnya. Ada negara yang membuka diri terhadap peran asing dalam pengelolaan SDA-nya ada juga yang bersifat terbatas dan ada pula yang tertutup sama sekali.

Persoalan mendasar yang melatarbelakangi pilihan-pilihan tersebut, terutama di negara-negara bekas kolonial adalah karena menguatnya sentimen nasionalisme dari bangsanya. Di sisi lain, persoalan pembangunan ekonomi yang membutuhkan kapital dan teknologi, pada umumnya menjadi persoalan tersendiri bagi negara-negara bekas kolonial tersebut, sehingga negara dalam kelompok ini biasanya membuka diri terhadap investasi asing, baik yang terbatas maupun yang liberal, yakni membuka diri dengan lebar terahdap berbagai jenis investasi asing dan dalam besaran nilai investasi yang mencapai $100 \%$.

\section{Implementasi KPSA dalam Aturan Kebijakan Investasi Asing di Aljazair}

Pilihan terhadap sistem pengelolaan SDA tentunya akan memiliki konsekuensi sendiri-sendiri. Namun pada umumnya, negara-negara dunia ketiga atau miskin dan berkembang lebih memilih terbuka terhadap uluran tangan asing. Hal ini dikarenakan tidak adanya modal dan teknologi yang dimilikinya, sehingga perlu bermitra dengan negara yang memiliki modal atau teknologi atau keduanya. Bagi negara-negara berkembang dan miskin ${ }^{24}$ yang umumnya terjadi di negaranegara bekas kolonial, seperti Afrika dan Asia, persoalan pembangunan ekonomi menjadi beban yang sangat berat selepas mereka merdeka dari para penjajah. Dalam kasus Afrika misalnya, selama beberapa dekade awal bahkan hingga saat ini, kemiskinan menjadi momok yang tak kunjung lepas dalam kehidupan negarnegara di Benua Hitam tersebut. Pada awal dicetuskannya Resolusi PBB tentang Permanent Sovereignty over Natural Resources (1964), negara-negara Afrika menyambutnya dengan penuh semangat nasionalisme untuk membangun

${ }^{24}$ Akibat kemiskinan yang berkepanjangan di Afrika, kondisi umum yang terjadi saat ini yang berkontribusi terhadap semakin akutnya kemiskinan adalah berbagai penyakit, seperti malaria dan penyakit-penyakit berinfeksi lainnya. Lihat Sambit Bhattacharyya, "Root Causes of Africa Underdevelopment", Journal of African Economies, Volume 18, Number 5, 2009, pp. 745-746. 
negaranya. Namun dalam prakteknya, sikap nasionalisme tersebut ke arah proteksionis terhadap investasi asing ${ }^{25}$. Misalnya, Aljazair, menyambut Resolusi PBB tersebut dengan melakukan pengaturan tentang investasi asing secara langsung terhadap sumber daya alam yang strategis dilakukan secara terbatas. Hal itu terlihat dari Aljazair Invesment Code of $1966^{26}$ yang secara tegas merinci mengenai jenis-jenis investasi yang boleh dilakukan secara langsung dan tidak langsung oleh pihak asing sebagai berikut:

a. the limitation of foreign investments to those sectors of the economy which are considered not to be vital to the national economy, unless the State specifically 'invites' foreign or domestic private investment to participate in those sectors, which, as a rule, can only be done in joint venture with an existing state owned enterprise;

$b$. tight control and state monopolies regarding commercial operations of any foreign companies and all foeign trade, as well as foreign exchange;

c. restrictions on ownership of immovable property by foreign companies or individuals;

d. mandatory local participantion rules normally providing that foreign investors could only operate as minority (49\%) equity partners of local (national) shareholders;

e. severe pinalties, which include confiscation, forfeiture and imprisonment, for any failure to comply with the administrative licensing conditions of any foreign invesment or the laws governing any related activities;

$f$. the discretionary granting of certain previlages, mainly customs and tax rebates and

g. foreign exchange exemptions, to foreign investments approved the authorities;

$h$. the general rule that all general commercial, other statutory and common law will only apply subjent to the special legislation foreign investments and commercial activities of foreign companies;

$i$. the existence of special legislation for mining, petroleum and gas eksplorations; and

$j$. compensation limited to the net value of assets in case of expropriation and only in so far as all licensing requirments are satisfied, such as compensation being convertible in to foreign exchange only up to the amunts of foreign capital actually and originally invested; and

k. submission of all legal interpretation and disputes to the national law and forum only.

Empat aturan pertama yang mempertegas sikap Aljazair terhadap kedaulatan sumber daya mereka dalam kaitannya dengan investasi asing, yakni pembatasan terahadap sumber daya alam yang memiliki nilai strategis kepada ekonomi mereka tidak bisa dibuka untuk investasi asing, kecuali negara sendiri yang berinisiatif

${ }^{25}$ Akinlo Taiwo and Simon-Oke O. Olayemi, "Re-examine foreign direct investment and economic growth: Panel co-integration and casuality test for sub-Saharan African countries", International Area Studies Review, Vol. 18 (1), 2015, pp. 74.

${ }^{26}$ Nama aslinya adalah the 1996: de Brauw. 
untuk membukanya kepada investor asing. Selanjutnya, pemerintah melakukan kontrol yang kuat dan sekaligus sebagai pihak yang paling utama dalam melakukan monopoli [aturan] terhadap aktivitas ekonomi dari pihak asing. Selain itu, yang perlu diperhatikan bahwa terhadap properti yang sifatnya tetap tidak boleh ada kepemilikan asing, serta aturan yang terakhir adalah bahwa maksimal saham asing yang boleh dimiliki adalah $49 \%$ sedangkan yang 51\% harus dimiliki oleh pihak dari dalam Aljazair sendiri. Khusus mengenai besaran share saham ini, Douga Wallace Atase Perdagangan Amerika untuk Afrika utara, pada tahun 2014 menyatakan bahwa aturan tersebut menjadikan Aljazair sebagai negara yang paling berat untuk tempat usaha. Bahkan, Pierre Gattaz, seorang Pebisnis dari Perancis dengan terus terang menyatakan ketakutannya melakukan investasi di Aljazair dengan aturan batas maksimal kepemilikan saham asing yang tidak boleh lebih besar (minority share) dibandingkan dengan kepemilikan investor dalam negeri ${ }^{27}$.

Aturan investasi di Aljazair tersebut memperlihatkan national interest yang tinggi sehingga investor asing harus mematuhi berbagai aturan restriksi yang dibuat oleh negara tersebut. Namun aturan itu pada perjalanan berikutnya mengalami berbagai perkembangan seiring dengan kebutuhan keterserapan tenaga kerja dan penciptaan lapangan pekerjaan, pembiayaan pembangunan dan lain sebagainya, sehingga beberapa deklarasi atau aturan mengenai Foreign Direct Investment (FDI) dibuat sedemikian rupa, namun masih tergolong rendah. Hal ini ditunjukkan dengan laju perkembangan FDI di Aljazair yang tertahan pada level $1.3 \%$ dalam skala global 28 .

Kebijakan proteksionis terhadap investasi asing di Aljazair tersebut berakibat pada ketakutan dari Investor asing untuk melakukan bisnis di Aljazair. Bahkan laporan dari UN Conference on Trade and Development (UNCTAD) 2017 lalu menunjukkan bahwa Foreign Direct Investment (FDI) di Aljazair secara umum terhadap berbagai jenis sektor ekonomi di negara tersebut, menurun secara drastis

27 The Arab Weekly, (01/07/2017). "Aljazair lags behind neighbours in attracting foreign investment", dalam https:// thearabweekly.com/Aljazair-lags-behind-neighbours-attracting-foreign-investment, diakses tanggal 4 Agustus 2018.

28 Andre Thmashausen, Loc. Cit., hlm. 153. 
sebanyak $26 \%$ setiap tahunnya (tabel 1). Terhadap laporan UNCTAD ini, media Aljazair melakukan pembelaan-dengan menyatakan bahwa penurunan investasi asing tersebut tidak bersifat tunggal, tetapi fenomena umum yang melanda seluruh kawasan Afrika. Menurut Ekonom Aljazair, Hassan Haddouch, fakta yang sesungguhnya adalah penurunan investasi asing di Afrika Utara sangat kecil yakni sebesar $4 \%$, misalnya di Maroko menurunnya memang agak tajam mencapai $23 \%$. Kondisi tersebut, menurut Haddauch, berakibat pada kemandekan investasi asing di Aljazair. Padahal, meskipun Aljazair memiliki sumber daya alam yang kuat, peluang pasar domestik yang terbuka, namun [dengan kebijakan] tersebut, Aljazair tetap kurang mampu menarik investor asing. Namun demikian, selain proteksionis, faktor lainnya yang menyebabkan kurangnya minat investor asing ke Aljazair adalah pembatasan saham asing maksimal sebesar 49\%, dan faktor lainnya adalah persoalan korupsi di tubuh birokrasi negara tersebut ${ }^{29}$.

Tabel 1

Perbanding FDI di Negara-negara Afrika Utara

\begin{tabular}{lllllll}
\hline \multicolumn{1}{c}{ Negara } & \multicolumn{1}{c}{$\mathbf{2 0 1 1}$} & $\mathbf{2 0 1 2}$ & $\mathbf{2 0 1 3}$ & \multicolumn{1}{c|}{$\mathbf{2 0 1 4}$} & \multicolumn{1}{c}{$\mathbf{2 0 1 5}$} & \multicolumn{1}{c}{$\mathbf{2 0 1 6}$} \\
\hline Aljazair & 2,580 & 1,499 & 1,684 & 1,507 & -584 & 1,546 \\
Mesir & -483 & 6,031 & 4,256 & 4,612 & 6,925 & 8,107 \\
Libya & - & 1,425 & 702 & $50^{\mathrm{b}}$ & $726^{\mathrm{b}}$ & $493^{\mathrm{b}}$ \\
Maroko & $2,568^{\mathrm{d}}$ & $2,728^{\mathrm{d}}$ & $3,298^{\mathrm{d}}$ & $3,561^{\mathrm{d}}$ & $3,255^{\mathrm{d}}$ & $2,322^{\mathrm{d}}$ \\
Sudan Selatan & - & $161^{\mathrm{b}}$ & $793^{\mathrm{b}}$ & $44^{\mathrm{b}}$ & $-71^{\mathrm{b}}$ & $-17^{\mathrm{b}}$ \\
Sudan & 1,734 & 2,311 & 1,688 & 1,251 & 1,728 & 1,064 \\
Tunisia & 1,148 & 1,603 & 1,117 & 1,064 & 1,002 & 958 \\
\hline
\end{tabular}

Sumber: UNCTAD, World Investment Report, 2017:222.

Situasi tersebut disadari sepenuhnya oleh Menteri Perindustrian Aljazair yang mengakui bahwa aturan kepemilikan saham tersebut menyebabkan Aljazair terisolasi dari percaturan perekonomian global, sehingga memiliki komitmen untuk melakukan perubahan yang mendasar terhadap aturan kepemilikan saham

${ }^{29}$ The Arab Weekly, Loc. Cit. Dalam laporan sepuluh tahun sebelumnya (2006), UNCTAD juga mencatat record yang sama mengenai renndahnya posisi FDI di Aljazair. Lihat analisisnya dalam Bensghir Karim, 2010. "Foreign Direct Investment in Aljazair and Its Impact on Economic Growth", Thesis, KDI School of Public Policy and Management, Korea Selatan, hlm. 16. 
asing tersebut yang lebih sesuai dengan aspirasi investor asing mengenai besaran saham yang bisa dimiliki oleh pihak asing ${ }^{30}$.

Keempat faktor tersebut terkonfirmasi oleh hasil kajian Elizabeth Asiedu ${ }^{31}$, yang melakukan survei terhadap para investor, menyatakan bahwa persoalan restriksi investasi, korupsi dan instabilitas politik telah berdampak buruk terhadap FDI di Afrika. Sebaliknya, pengurangan angka korupsi, sebagaimana terjadi di Nigeria, berdampak positif terhadap minat investor asing di negara tersebut sebagaimana yang dialami oleh Afrika Selatan.

Dalam kaitannya dengan FDI di Aljazair pada sektor Sumber Daya Alam Strategis seperti mineral dan tambang, maka berdasarkan UU Investasi Aljazair No. 49/51 yang secara efektif berlaku sejak 2006, tetap menunjukkan watak restriktif yang mengharuskan kepemilikan saham dalam negeri harus mayoritas, yakni mencapai 51\%. Awalnya, aturan ini hanya berlaku untuk sektor minyak bumi namun kemudian pada 2009 diberlakukan untuk semua jenis investasi di Aljazair ${ }^{32}$. Pada 2016 seiring dengan diundangkannya UU Keuangan Aljazair (Finance Law) yang baru, melakukan koreksi terhadap restriksi kepemilikan saham asing yang diatur pada UU Investasi Aljazair No. 49/50 tersebut-yang melokalisir terhadap sektor-sektor investasi dalam bidang produksi barang dan jasa-jasa saja yang kepemilikan sahamnya harus dimiliki oleh peserta dalam negeri mencapai $51 \% 33$. Namun demikian, tidak juga dijelaskan mengenai ketentuan maksimal kepemilihan saham asing pada sektor SDA strategis. Hal ini menunjukkan sikap Aljazair yang masih berorientasi sikap proteksionis terhadap kehadiran investor asing di negeri tersebut. Situasi ini yang menyebabkan masih melambannya pertumbuhan FDI di Aljazair.

\footnotetext{
${ }^{30}$ Michael L. Coleman, Celine Van Zeebroeck and Jessica Norrant-Eyme, 2016. "Aljazair: New Investment Code", dalam < https://www.lexology.com/library/detail.aspx?g=e3f56ae8-a2f4-4cf2-a66f-799d227564a7>, diakses tanggal 6 Agustus 2018.

31 Alizabeth Asiedu, "Foreign Direct Investment in Africa: The Role of Natural Resources, Market Size, Government Policy, Institutions and Political Instability", The World Economy, Vol. 29 Issue 1, January 2006, pp.6377.

${ }^{32}$ Namun 'perlakuan istimewa' diberikan terhadap perusahaan-perusahaan Amerika dari ketentuan kepemilikan saham mayoritas-minoritas tersebut. Perusahaan-perusahaan Amerika diberikan 'hak' untuk melakukan regulasi tersendiri dalam menentukan besaran divestasi saham perusahaanya kepada peserta dalam negeri Aljazair. Lihat dalam https://www.export.gov/article?id=Aljazair-openness-to-foreign-investment, diakses tanggal 25 Agustus 2018.

33 Lihat http://www.nortonrosefulbright.com/knowledge/publications/142981/new-investment-law-inAljazair-an-overview-of-what-it-does-and-does-not-change-for-foreign-investors
} 


\section{Penerapan KPSA dalam aturan Kebijakan Investasi Asing di Indonesia}

Kehadiran investasi asing di suatu negara, khususnya investasi asing langsung, diharapkan mampu memberikan dampak positif bagi pembangunan dan pertumbuhan ekonomi. Dalam konteks Indonesia sebagai salah satu negara berkembang, yang juga bergantung dengan kerjasama dari negara lain, menyadari bahwa untuk melakukan perbaikan stabilitas ekonomi diperlukan peningkatan daya saing negara dalam menarik investor asing. Undang-Undang Nomor 25 Tahun 2007 tentang Penanaman Modal diundangkan sebagai pengganti UndangUndang Nomor 1 Tahun 1967 tentang Penanaman Modal Asing dan UndangUndang Nomor 6 Tahun 1968 tentang Penanaman Modal Dalam Negeri. Pemberlakuan undang-undang penanaman modal ini bertujuan memperbaiki dan meningkatkan kepercayaan investor (terkait dengan FDI) untuk kembali menanamkan modalnya di Indonesia.

Foreign Direct Investment (FDI) ${ }^{34}$ atau Penanaman Modal Asing secara langsung merupakan salah satu pembiayaan (modal) yang penting bagi suatu negara terlebih bagi negara-negara berkembang dan negara-negara miskin. FDI menjadi salah satu faktor penting di dalam perekonomian negara disamping pajak sebagai faktor terbesar penyumbang keuangan negara. Sebab, FDI mampu memberikan kontribusi yang cukup besar bagi pembangunan melalui transfer aset, transfer manajemen, dan juga transfer teknologi guna mendorong pertumbuhan dan peningkatan perekonomian negara.

Pemilihan investasi oleh investor melalui jalur FDI dikarenakan investasi semacam ini merupakan bentuk aliran modal yang bersifat jangka panjang dan

\footnotetext{
34 Menurut jenisnya, FDI dibagi menjadi dua, yaitu: FDI vertical, FDI yang dilakukan secara vertikal menyangkut desentralisasi secara geografis dari aliran produksi perusahaan. Perusahaan akan melakukan kegiatan produksi di negara-negara yang memiliki biaya tenaga kerja yang rendah, kemudian hasil produksi di negara tersebut akan disalurkan kembali ke negara induk. FDI juga dapat dibedakan menjadi jenis greenfield dan akuisisi (pengambilalihan). Investasi dengan jenis greenfield akan membangun unit produksi yang baru sementara FDI dengan tipe akuisisi akan membeli sebagian kepemilikan dari perusahaan yang sudah ada sebelumnya. Sementara itu, FDI juga dapat dibedakan berdasarkan motivasi yang melatarbelakangi investor asing, yaitu: Resource seeking: Investasi dilakukan untuk mencari faktor-faktor produksi yang lebih efisien di negara lain dibandingkan dengan menggunakan faktor produksi di dalam negeri yang lebih mahal, Market seeking: Investasi yang dilakukan dengan tujuan mencari pasar yang baru atau mempertahankan pasar yang lama. Strategi ini dapat juga dilakukan sebagai strategi pertahanan. Investasi dengan latar belakang untuk mencari pasar direalisasikan di dalam bentuk merger dan akuisisi, dan Efficiency seeking: Investasi dimana perusahaan berusaha untuk meningkatkan efisiensinya dengan mengambil keuntungan dari economic scale dan scope. Tipe FDI ini banyak digunakan di negara-negara berkembang. Lihat Anugrah Widyastuti, "Implementasi Foreign Direct Investment di Indonesia: Sebelum dan Setelah diundangkannya Undnag-Undang Nomor 25 Tahun 2007 tentang Penanaman Modal”, Pandecta: Research Law Journal, Vol. 6 No. 2 (2011), hlm.141.
} 
relatif tahan atau stabil terhadap gejolak perekonomian. Terkait dengan hal itu, maka Indonesia, sebagai salah satu negara berkembang dan negara di Asia khususnya di kawasan Asia Tenggara, memiliki potensi yang sangat besar untuk menarik minat investor untuk menanamkan modalnya di Indonesia ${ }^{35}$.

Dalam sejarahnya, FDI di Indonesia dimulai pada era Kolonial Belanda (18701941), kemudian diikuti oleh Jepang pada periode 1942-1945. Setelah Indonesia, bebas dari Jepang dan beralih kepada Orde Lama (1945-1965), perhatian pemerintah terhadap FDI sangat rendah. Hal ini dikarenakan, konsentrasi pemerintah Orde Lama fokus kepada transisi dari kolonial dan juga stabilitas politik dan militer dalam negeri yang masih belum mapan. Kemudian setelah era Orde Lama selesai digantikan Orde Baru (1966-1999), situasi berbalik drastis, dimana keyakinan Orde Baru pada pertumbuhan ekonomi, menjadikan FDI sebagai motor penggeraknya. FDI diyakini tidak hanya membawa kapital tetapi juga teknologi dan skill yang memadai untuk menopang pembangunan. Kebijakan ini terus berlanjut sampai era reformasi ${ }^{36}$ [bahkan] sekarang jauh liberal kebijakan investasi yang dicanangkan oleh Pemerintah melalui skema FDI sebagaimana terlihat pada tabel 2.

Sebelum diundangkannya undang-undang terbaru di bidang investasi di 2007, berdasarkan data investasi di Indonesia, sejak 1998-2000, aliran FDI yang masuk ke Indonesia mengalami penurunan (terutama saat terjadi krisis ekonomi) secara signifikan yaitu 2,7\% selama 3 tahun. Hal ini menunjukkan bahwa investasi yang terjadi cenderung negatif (jumlah investasi yang keluar lebih besar daripada investasi yang masuk). Setelah 2000, perubahan iklim investasi di Indonesia mengalami peningkatan dan menuju ke arah yang lebih baik terlebih dengan investasi yang masuk terutama di bidang merger dan akuisisi perusahaanperusahaan di dalam negeri ${ }^{37}$.

\footnotetext{
${ }^{35}$ Mengenai jenis-jenis investasi terbuka dan tertutup untuk investor asing dan dalam negeri saat ini diatur oleh Peraturan Presiden Nomor 44 Tahun 2016.

36 Abdul Kholiq dan Ilan Noy, "Foreign Direct Investment and Economic Growth: Empirical Evidence from Sectoral Data in Indonesia", Working Paper, Departemen of Economic, University of Hawaii at Manoa, 2007, hlm.10-11.

37 Anugrah Adiastuti, Loc. Cit., hlm. 140-142.
} 
Dalam konteks itu, sejak diundangkannya Undang-Undang Nomor 25 Tahun 2007 tentang Penanaman Modal, perekonomian Indonesia mulai mengalami perbaikan secara bertahap. Hal ini dapat dilihat dari adanya ketentuan yang mendasar mengenai masuknya dan berjalannya investasi (dalam hal ini FDI) ke Indonesia, yaitu perbaikan di dalam sektor pelayanan dan sektor yang dapat dimasuki oleh investor terkait dengan upaya peningkatan investasi ${ }^{38}$.

Sementara itu, terkait dengan sifat FDI di Indonesia pada bidang usaha terbuka, termasuk sumber daya alam strategis bagi kepentingan dan keberlangsungan perekonomian Indonesia yaitu mineral ${ }^{39}$ dan batu bara, kedua jenis SDA ini dikualifikasikan sebagai SDA yang memiliki nilai strategis karena merupakan kekayaan alam tak terbarukan sebagai karunia Tuhan Yang Maha Esa yang mempunyai peranan penting dalam memenuhi hajat hidup orang banyak. Atas dasar pemikiran ini, maka pengelolaan SDA dalam kelompok ini harus dikuasai oleh Negara untuk memberi nilai tambah secara nyata bagi perekonomian nasional dalam usaha mencapai kemakmuran dan kesejahteraan rakyat secara berkeadilan 40 .

Berdasarkan data pada tabel 2 dari lampiran Perpres Nomor 44 Tahun 2016 tentang Daftar Bidang Usaha yang Tertutup dan Bidang Usaha yang Terbuka dengan Persyaratan di Bidang Penanaman Modal, menunjukkan 'liberalisasi investasi'41 dalam arti tidak ada restriksi bagi pihak asing untuk melakukan investasi di Indonesia. Selain itu, besaran nilai investasinyapun juga beragam dari $49 \%$ batas kepemilikan saham asing yang terendah sampai mencapai $95 \%$

38 Ibid.

39 Dalam ketentuan Pasal 1 [4] UU No. 4 Tahun 2009 tentang Pertambangan Mineral dan Batu Bara disebutkan bahwa Pertambangan Mineral adalah pertambangan kumpulan mineral yang berupa bijih atau batuan, di luar panas bumi, minyak dan gas bumi, serta air tanah.

40 Lihat bagian Konsideran "Mengingat" butir (a) jo. Pasal 4 UU Nomor 4 Tahun 2009 Tentang Pertambangan Mineral dan Batu Bara. Ketentuan mengenai tambang sebagai salah satu kelompok sumber daya alam yang strategis, regulasi yang mengaturnya mengalami perkembangan paradigma. Dalam UU No. 11 Tahun 1967, penggolongan bahan galian lebih ditekankan pada pertimbangan aspek politis dikaitkan dengan kepentingan ketahanan dan pertahanan nasional, dan terbagi dalam tiga golongan (a. golongan bahan galian strategis; b. golongan bahan galian vital. c. golongan bahan galian yang tidak termasuk dalam golongan a atau b). Sedangkan dalam UU No. 4 Tahun 2009, penggolongan bahan galian lebih rnenitikberatkan pada aspek teknis, yaitu berdasarkan pada kelompok atau jenis bahan galian.

${ }^{41}$ Liberalisasi investasi sebetulnya di Indonesia dimulai sejak tahun 1967, ketika diundangkannya UU Nomo 1 Tahun 1967. Sejak itu, Indonesia menjadi daya tarik tersendiri bagi investor asing untuk melakukan investasi. Lihat Abdul Kholiq, Loc. Cit., hlm. 2. 
tertingginya khususnya untuk investasi bidang energi maupun mineral yang memerlukan teknologi modern tingkat tinggi.

Tabel 2

Besaran Investasi Asing bidang SDA Energi dan Sumber Daya Mineral

\begin{tabular}{|c|c|c|}
\hline No & Bidang Investasi & $\begin{array}{c}\text { Besaran Saham Asing } \\
\text { Maksimal (\%) }\end{array}$ \\
\hline 1 & Jasa Konstruksi Migas: Platform & 75 \\
\hline 2 & Jasa Konstruksi Migas: Tangki Spherical & 49 \\
\hline 3 & $\begin{array}{l}\text { Jasa Konstruksi Migas: Instalasi Pipa } \\
\text { Penyalur di Laut }\end{array}$ & 49 \\
\hline 4 & Jasa Survei Migas, Geologi dan Geofisika & 49 \\
\hline 5 & Jasa Survei Panas Bumi & 95 \\
\hline 6 & Jasa Pemboran Migas di Laut & 75 \\
\hline 7 & Jasa Pemboran Panas Bumi & 95 \\
\hline 8 & $\begin{array}{l}\text { Jasa Pengoperasian dan Pemeliharaan } \\
\text { Panas Bumi }\end{array}$ & 90 \\
\hline 9 & Pembangkit Listrik Skala Kecil (1-10 MW) & 49 \\
\hline 10 & $\begin{array}{l}\text { Pembangkit Listrik Tenaga Panas Bumi } \\
\text { dengan Kapasitas } \leq 10 \mathrm{MW}\end{array}$ & 67 \\
\hline 11 & Pembangkit Listrik > $10 \mathrm{MW}$ & 95 dan 100 (KPS) \\
\hline 12 & Transmisi Tenaga Listrik & 95 dan 100 (KPS) \\
\hline 13 & Distribusi Tenaga Listrik & 95 dan 100 (KPS) \\
\hline 14 & Konsultasi dibidang Instalasi Tenaga Listrik & 95 \\
\hline 15 & $\begin{array}{l}\text { Pembangunan dan Pemasangan Instalasi } \\
\text { Tenaga Listrik atas Instalasi Penyediaan } \\
\text { Tenaga Listrik }\end{array}$ & $\begin{array}{l}95 \text { [49 untuk tegangan } \\
\text { tinggi } \\
100 \text { untuk tegangan } \\
\text { rendah] }\end{array}$ \\
\hline 16 & $\begin{array}{l}\text { Pengoperasian dan Pemeliharaan Instalasi } \\
\text { Tenaga Listrik }\end{array}$ & 95 \\
\hline 17 & $\begin{array}{l}\text { Pemeriksaan dan Pengujian Instalasi } \\
\text { Tenaga Listrik atas Instalasi Penyediaan } \\
\text { Tenaga Listrik atau Pemanfaatan Tenaga } \\
\text { Listrik Tegangan Tinggi }\end{array}$ & $\begin{array}{l}49 \text { (100 untuk tegangan } \\
\text { rendah) }\end{array}$ \\
\hline
\end{tabular}

Sumber: Diolah dari lampiran Perpres Nomor 44 Tahun 2016

Bahkan liberalisasi investasi asing juga terlihat jelas dalam paket kebijakan Paket kebijakan jilid X yang dicanangkan Presiden Joko Widodo yang berisi perubahan tentang daftar negatif investasi (DNI) yang sebelumnya diatur dalam Peraturan Presiden (Perpres) Nomor 39 Tahun 2014. Paket kebijakan ini memuat ketentuan investasi untuk bidang-bidang usaha yang mulai dibuka untuk investor 
asing dengan jumlah kepemilikan tertentu dan bidang-bidang usaha yang porsi saham asingnya diperbesar hingga $100 \%{ }^{42}$.

Disebutkan lebih lanjut dalam paket kebijakan tersebut bahwa konkritnya ada 17 bidang usaha yang porsi kepemilikan sahamnya boleh dikuasai asing hingga 100\% sebagaimana pada tabel 2 di atas. Lebih liberalnya lagi dijelaskan bahwa industri yang $100 \%$ sahamnya dikuasai penanaman modal asing (PMA) ini tidak harus bermitra dengan perusahaan lokal. Namun demikian, meskipun kepemilikan saham asing sampai bisa mencapai $100 \%$, ada ketentuan divestasi bagi investor asing di bidang pertambangan. Hal itu ditegaskan dalam ketentuan Pasal 112 Undang-Undang No. 4 Tahun 2009 tentang Pertambangan Mineral dan Batubara mengatur bahwa setelah 5 tahun berproduksi, badan usaha pemegang izin usaha pertambangan yang sahamnya dimiliki oleh asing wajib melakukan divestasi saham. Divestasi ini dilakukan pada Pemerintah, pemerintah daerah, badan usaha milik negara, badan usaha milik daerah, atau badan usaha swasta nasional. Pasal 97 ayat (2) Peraturan Pemerintah No. 1 Tahun 2017 [Perubahan Keempat] ${ }^{43}$ tentang Pelaksanaan Kegiatan Usaha Pertambangan Mineral dan Batubara selanjutnya mengatur besaran saham yang harus didivestasi, yaitu sehingga sahamnya paling sedikit 20\% dimiliki peserta Indonesia. Demikian selanjutnya $30 \%$ pada tahun ketujuh, 37\% tahun kedelapan, $44 \%$ tahun kesembilan dan $51 \%$ pada tahun kesepuluh.

Situasi tersebut dalam konteks Indonesia dalam perjalannya terkadang mengalami dilema. Contoh yang paling sering terjadi dan menjadi sorotan publik adalah investasi Freeport di Papua yang sudah puluhan tahun—dengan besaran investasi mencapai 97,3\% dan Indonesia 9,3\%. Dan baru saat ini sedang dilakukan proses divestasi saham menjadi $51 \%$ yang proses negosiasinya masih panjang dan dengan tingkat resiko gagalnya juga masih sangat tinggi.

\section{Penutup}

Perjalanan panjang doktrin kedaulatan permanen atas sumber daya alam sejak pertama kali dicetuskan oleh PBB pada akhir dekade tahun 1950, telah

\footnotetext{
${ }^{42}$ Investor Daily, 12 Februari 2016, Liberalisasi Investasi Asing, dalam <http://id.beritasatu.com/home/liberalisasi-investasi-asing/139429>, diakses tanggal 2 Agustus 2018.

${ }^{43}$ Saat ini sudah diterbitkan PP No. 8 Tahun 2018 sebagai perubahan kelima. Dalam Pasal 85A dilakukan perubahan tentang penetapan harga jual batu bara tersendiri untuk memenuhi kebutuhan dalam negeri.
} 
mengalami dinamika perkembangan yang sangat pesat-dari yang awalnya dipraktekkan secara tradisional untuk kepentingan nasional suatu negarakemudian berkembang dan bersinggungan dengan berbagai isu ekonomi global, lingkungan, HAM dan perubahan iklim. Oleh sebab itu, setiap negara memiliki hak yang sama dan secara bebas mengelola peruntukan anugerah Tuhan tersebut sesuai dengan tujuan dari masing-masing negara yang ditegaskan dalam konstitusinya. Dalam praktek negara-negara Afrika, implementasi pengelolaan kedaulatan permanen atas sumber daya alam (KPSA) seperti di Aljazair bersifat selektif atau tidak liberal, tertutama pada sumber daya alam yang memiliki nilai strategis bagi hajat hidup masyarakatnya. Namun hal ini ternyata menjadi penghalang minat investor-investor dari luar negeri dan membuat pertumbuhan FDI di negara tersebut relatif lambat.

Dalam parktek di Indonesia sebagai negara berkembang yang saat ini sedang giat-giatnya membuka diri terhadap investor lokal maupun internasional guna meningkatkan perekonomian nasional untuk kesejahteraan masyarakat, pengelolaan KPSA pada kebijakan FDI bersifat liberal. Hal ini tidak terlepas dari energi pemerintah untuk mengejar ketertinggal dari negara-negara tetangga maupun negera lainnya. Namun demikian, Indonesia tetap mencoba bersikap moderat dengan melakukan divestasi saham mayoritas dalam usaha-usaha tertentu.

\section{Daftar Pustaka}

\section{Buku}

Acemoglu, Daron dan James A. Robinson, Why Nations Fail: The Origin of Power, Prospherity, and Poverty. Crown Business, New York, 2012.

Adam, William M and Martin Mulligan, Decolonizing Nature: Strategies for Conservation in a Post-colonial Era, Earthscan Publications Ltd, London, 2003.

Amstrong, Chris, Melawan Kedaulatan Permanen atas Sumber Daya, University of Southampton, Politics, Philosophy and Economics, 2014.

Sugiyono, Metode Penelitian Administrasi, Bandung: Penerbit Alfabet, 2004.

Thomashausen, Andre, (Forein) Investment Strategies inAfrica dalam Marc Bungenber dan Stephan Hobe (Eds). Permanent Sovereignity over Natural Resources, Switzerland: Springer International Publishing, 2015. 


\section{Jurnal}

Asiedu, A., "Foreign Direct Investment in Africa: The Role of Natural Resources, Market Size, Government Policy, Institutions and Political Instability", The World Economy, Vol. 29 Issue 1, January 2006.

Atsegbua, L. 1993. "Principle Of Permanent Sovereignty Over Natural Resources and Its Contribution to Modern Petroleum Development Agreements". Journal of the Indian Law Institute, 35(1/2), 115-126. Retrieved from http://www.jstor.org/stable/43952327.

Bhattacharyya, S. "Root Causes of Africa Underdevelopment", Journal of African Economies, Volume 18, Number 5, 2009.

Bungenber, Marc, dan Stephan Hobe (Eds), Permanent Sovereignity over Natural Resources, Switzerland: Springer International Publishing, 2015.

Gylfason, Thorvaldur dan Gylfi Zoega, Natural Resources and Economic Growth: The Role of Investment, The World Economy, Blackw ell Publishing L.td. Oxford, 2006.

Hannum, Hurs, Authonomy, Sovereignty, and Self Determination: The Accommodation of Conflicting Rights, University of Philadelpia Press, 2016.

Riduwan, Metode E Teknik Menyusun Tesis, Bandung: Penerbit Alfabet, 2004.

Schrijver, Nicolaas Jan, Sovereignty over Natural Resources: Balancing Rights and Duties in an Interdependent World, s.n. University of Groningen, 1995.

Schwebel, Stephen M., The Story of the U.N.'s Declaration on Permanent Sovereignity over Natural Resources, American Bar Association Journal, Vol. 49, No. 5 (MAY 1963).

Strang, D., "From Dependency to Sovereignty: An Event History Analysis of Decolonization 1870-1987". American Sociological Review, 55(6), 1990. Retrieved from http://www.jstor.org/stable/2095750.

Taiwo, A., and Simon-Oke O. Olayemi, "Re-examine foreign direct investment and economic growth: Panel co-integration and casuality test for sub-Saharan African countries", International Area Studies Review, Vol. 18 (1), 2015.

Waart, P. De., "Permanent Sovereignty over Natural Resources as a Corner-stone for International Economic Rights and Duties". Netherlands International Law Review, 24(1-2), 1977. doi:10.1017/S0165070X00016302.

Widyastuti, A., "Implementasi Foreign Direct Investment di Indonesia: Sebelum dan Setelah diundangkannya Undnag-Undang Nomor 25 Tahun 2007 tentang Penanaman Modal", Pandecta: Research Law Journal, Vol. 6 No. 2 (2011).

\section{Hasil Penelitian/Tugas Akhir}

Karim, Benshir, "Foreign Direct Investment in Aljazair and Its Impact on Economic Growth", Thesis, KDI School of Public Policy and Management, Korea Selatan, 2010. 
Kholiq, A., dan Ilan Noy, "Foreign Direct Investment and Economic Growth: Empirical Evidence from Sectoral Data in Indonesia", Working Paper, Departemen of Economic, University of Hawaii at Manoa, 2007.

WTO, "Natural Resources: Definitions, Trade Patterns and Globalization", World Trade Report, 2010.

Dhuhita Driyah Supapti, "Dialektika Hukum Investasi Nasional”, Paper disampaikan dalam Dies Natalis Fakultas Hukum, UNNES, Semarang, 30 November 2018.

\section{Internet}

Coleman, Michael L., Celine Van Zeebroeck and Jessica Norrant-Eyme, 2016. "Aljazair: New Investment Code", dalam < https:/ /www.lexology.com/library/detail.aspx?g=e3f56ae8-a2f4-4cf2a66f-799d227564a7>, diakses tanggal 6 Agustus 2018.

Investor Daily, 12 Februari 2016, Liberalisasi Investasi Asing, dalam <http://id.beritasatu.com/home/liberalisasi-investasi-asing/139429>, diakses tanggal 2 Agustus 2018.

The Arab Weekly, (01/07/2017). "Aljazair lags behind neighbours in attracting foreign investment", dalam https://thearabweekly.com/Aljazair-lagsbehind-neighbours-attracting-foreign-investment, diakses tanggal 4 Agustus 2018.

https: / / www.export.gov / article?id=Aljazair-openness-to-foreign-investment, diakses tanggal 25 Agustus 2018.

http:/ / www.nortonrosefulbright.com/knowledge/publications/142981/newinvestment-law-in-Aljazair-an-overview-of-what-it-does-and-does-notchange-for-foreign-investors

\section{Peraturan Perundang-undangan}

Undang-Undang Nomor 25 Tahun 2007 tentang Penanaman Modal

Peraturan Pemerintah Nomor 1 Tahun 2017 [Perubahan Keempat] tentang Pelaksanaan Kegiatan Usaha Pertambangan Mineral dan Batubara.

Peraturan Presiden Nomor 39 tahun 2014 Tentang Daftar Bidang Usaha yang Tertutup dan Bidang Usaha yang Terbuka dengan Persyaratan di Bidang Penanaman Modal.

Peraturan Presiden Nomor 44 Tahun 2016 tentang Daftar Bidang Usaha yang Tertutup dan Bidang Usaha yang Terbuka dengan Persyaratan di Bidang Penanaman Modal

UNCTAD, 2017. World Investment Report: Investment and The Digital Economy, United Nations. 